\title{
Gold shares or krugerrands - which is the better investment?
}

\author{
J.F. Affleck-Graves and G.D.I. Barr \\ University of Cape Town, Rondebosch
}

In this study we examine the performance of krugerrands vis-à-vis gold shares on the Johannesburg Stock Exchange over the period 1980 - 1983. Using the Markowitz portfolio selection model and Sharpe's capital market theory we are able to demonstrate that over the past few years, krugerrands have produced sub-optimal returns for the South African investor. This follows because in each year the investor would have been better off in some combination of gold shares and treasury bills rather than in krugerrands, no matter what risk level he chose. Furthermore, even in the naive case where the investor merely buys the gold share index, krugerrands are shown to be an inferior investment. S. Afr. J. Bus. Mgmt. 1986, 17: 49-55

In hierdie studie word die prestasie van Krugerrande vis-àvis goudaandele op die Johannesburgse Effektebeurs ondersoek vir die periode 1980 - 1983. Die skrywers maak gebruik van Markowitz se portefeuljeseleksiemodel en Sharpe se kapitaalmarkteorie om aan te toon dat die Krugerrand oor die afgelope paar jaar sub-optimale opbrengste gelewer het vir die Suid-Atrikaanse belegger. Dit is ooglopend aangesien die belegger elke jaar beter sou gedoen het met 'n kombinasie van goudaandele en skatkiswissels, eerder as Krugerrande, afgesien van die risikovlak gekies. Verder word Krugerrande as 'n swakker belegging aangetoon, selfs waar die naïewe belegger slegs die goudaandeel-indeks koop.

S.Afr. Tydskr. Bedryfsl. 1986, 17: 49-55

\section{J.F. Affleck-Graves*}

Graduate School of Business, University of Cape Town, Private Bag, Rondebosch 7700 Republic of South Africa

\section{G.D.I. Barr}

Department of Mathematical Statistics, University of Cape Town, Private Bag, Rondebosch, 7700 Republic of South Africa

*To whom correspondence should be addressed

\section{Introduction}

Gold bullion sales and the gold price are clearly items of tremendous importance to all South African investors because of the effect they have on the entire economy. But, in addition to their importance because of their overall effect, they are also important investment mediums in their own right. In fact, many South African investors adopt an almost reverential attitude to gold and discussion of the pros and cons of investment in the metal is liable to attract patriotic responses. It is therefore not surprising that South African investors are well catered for in terms of potential gold-related investments, with two distinct gold-based investment mediums being quoted on the Johannesburg Stock Exchange (JSE). These are the gold shares (quoted companies) and the krugerrand.

In recent years a great deal of interest has been shown in these two investment mediums with most investors holding an investment in either gold shares or krugerrands or both. It is therefore of considerable interest to examine the ex-post behaviour of gold shares vis-à-vis the krugerrand. In particular, it is of interest to determine whether ex-post, gold shares or krugerrands have provided the better investment opportunity for a South African investor or indeed, whether the investor's funds should have been divided with a certain proportion of them being placed in krugerrands and a certain proportion in gold shares.

\section{The portfolio selection model}

In 1952 Markowitz published his seminal paper on portfolio selection. This paper has formed the basis of all modern portfolio theory and is based on the assumption that only two factors need to be considered in choosing a portfolio, namely the return the investor can expect to receive from holding the portfolio and the uncertainty or risk associated with this return. Traditionally return has been calculated in the accepted manner as receipts (selling price plus dividends) less expenditure (purchase price) divided by expenditure. This method has been followed in this article.

The measurement of risk has proved much more contentious but the most widely accepted measure has been the deviation of return and this approach has been adopted in this article. The result is that any portfolio can be represented as a single point in a risk-return diagram. In fact, all possible portfolios (that is, all possible combinations of securities) will fill some region in this risk-return space. The basis of Markowitz's contribution to Finance is that a set of portfolios can be found which will dominate all other portfolios in the sense that for these portfolios it is not possible to obtain either a 
greater expected return without incurring greater risk or to obtain smaller risk without decreasing expected return. This special set of portfolios is known as the efficient set and it is clear that any investor would only wish to hold a portfolio belonging to this efficient set. This is shown diagrammatically in Figure 1 where curve $A B$ represents the efficient set.

William Sharpe (1964) used Markowitz's basic ideas to extent the portfolio selection model and derived the wellknown capital market theory. This theory was based on the assumption that investors were faced not only with a choice of risky assets but that they could also invest in a so-called 'risk free' asset such as treasury bills. Sharpe in fact derived his capital market theory on the assumption that investors could borrow or lend at the same risk-free rate. That is, it is assumed that the investor will be able to borrow additional funds to invest in risky assets. In this situation the sketch in Figure 1 will be altered to that which the situation in Figure 2 pertains.

The original efficient set $\mathrm{AB}$ has been altered by the inclusion of the risk-free asset ( $\left.R_{s}\right)$. The new efficient frontier is represented by the curve $R_{s} M L$. Points on the curve $A B$ which were previously efficient are now clearly inefficient because for these points one can obtain higher returns on the curve $\mathbf{R}_{\mathbf{s}} \mathrm{ML}$ for no additional risk. Any rational investor will therefore choose one of the portfolios on the curve $\mathrm{R}_{\mathrm{S}} \mathrm{ML}$.

\section{The data}

The basic data used in this study consisted of the weekly closing price of $\mathbf{4 5}$ gold shares quoted on the JSE as well as

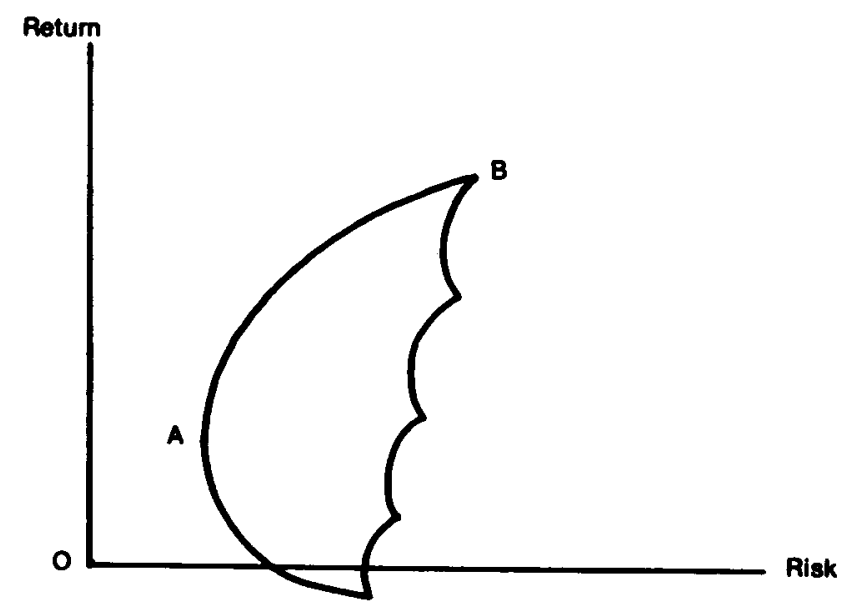

Figure 1 The efficient set of portfolios according to Markowitz (1952)

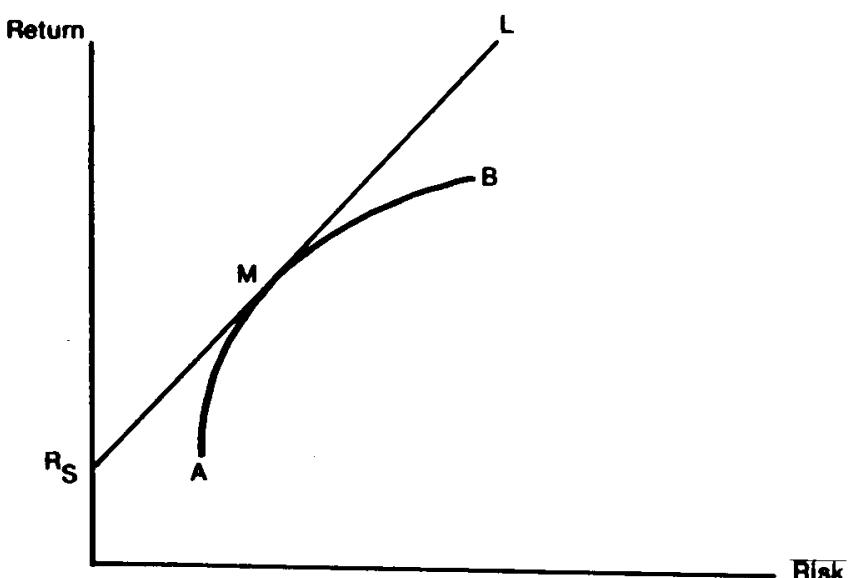

Figure 2 The new efficient frontier after inclusion of the risk free asset $\left(\mathbf{R}_{\mathbf{s}}\right)$
Table 1 Summary of gold index and krugerrand performance

\begin{tabular}{|c|c|c|c|c|}
\hline Date & $\begin{array}{l}\text { JSE Act. All } \\
\text { Gold Index }\end{array}$ & $\%$ Return & Krugerrand & $\%$ Retum \\
\hline 23.05 .80 & 519 & & 520 & \\
\hline 24.12 .80 & 728 & 40,3 & 630 & 21,2 \\
\hline 18.12 .81 & 572 & $-21,4$ & 455 & $-27,8$ \\
\hline 20.12 .82 & 792 & 38,5 & 568 & 24,8 \\
\hline 12.04 .83 & 813 & 2,6 & 549 & $-3,4$ \\
\hline Overall & - & 56,6 & - & 5,6 \\
\hline
\end{tabular}

the weekly closing price of the krugerrand as quoted on the JSE. The following five gold shares were excluded from the study:

1. EGOLI MINING COMPANY LIMITED

2. FALCON MINES LIMITED

3. PRIMROSE GOLD MINING COMPANY (1934) LIMITED

4. SOUTH ROODEPOORT MAIN REEF AREAS LIMITED

5. WITWATERSRAND GOLD MINING COMPANY LIMITED

These five securities were omitted because of the lack of sufficient data on these shares on the UCT computer share data base.

The period for which the data were analysed was 23 May 1980-12 April 1983 and a summary of statistics is given in Table 1 .

\section{Selection of efficient portfolios}

Using the data described above, efficient portfolios were generated for each of four non-overlapping periods. These periods were: 23 May 1980-24 December 1980; 9 January 1981-18 December 1981; 8 January 1982-20 December 1982; and 4 January $1983-12$ April 1983.

It must be stressed that these four periods were chosen for convenience and not because of any market or economic considerations. The starting date represents the time at which the krugerrand was first quoted on the JSE whereas the closing date represents the final date for which data were available on the UCT computer.

Two different efficient frontiers were generated for each period and these are shown in Figures $3-6$. The first efficient frontier is labelled SJMQ and was derived from the 45 gold shares listed in Appendix A. This frontier thus represents the efficient portfolios that were available to shareholders who wished to invest in gold shares only. The second efficient frontier is labelled KJMQ and was determined using not only the $\mathbf{4 5}$ gold shares but also the krugerrand. It thus indicates the advantage, if any, that will accrue to an investor who includes krugerrands in his portfolio in addition to gold shares.

In addition to these two efficient frontiers, Figures 3-6 also indicate the capital market line for each year. This line is drawn tangent to the efficient frontier from a point on the return axis equal to the risk-free rate. It represents the efficient frontier for an investor who would have chosen his portfolio from the $\mathbf{4 5}$ gold shares considered in this study, the krugerrand, and treasury bills (assumed to be the risk-free asset for this study). As mentioned previously the capital market line is a straight line and is indicated by $R_{S} M L$ in Figures 3-6.

\section{Composition of efficient portfolios}

Examination of Figures 3-6 indicates that the range and shape of the efficient set is markedly different in each period. 


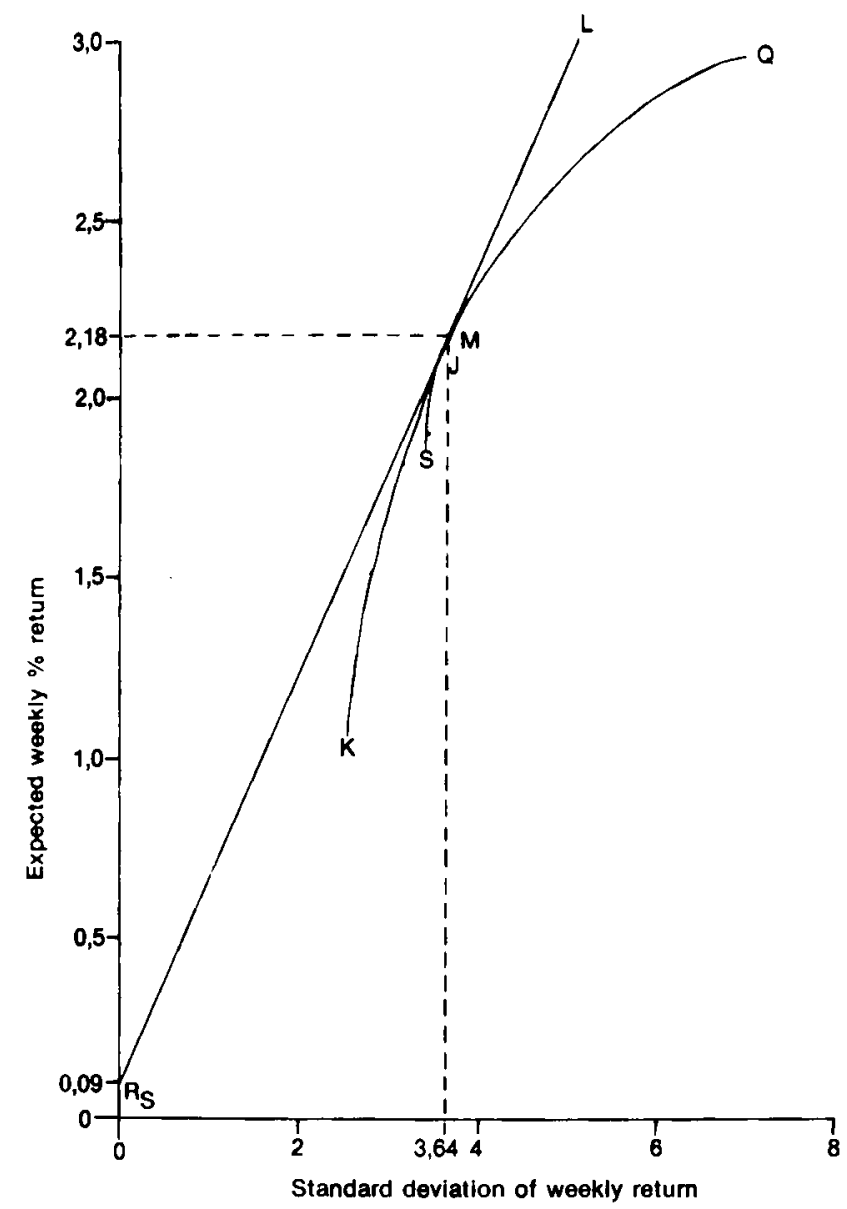

Figure 3 Efficient portfolios of SA gold shares and 1 oz krugerrand. Investment period: 23 May 1980-24 December 1980 (32 weeks)

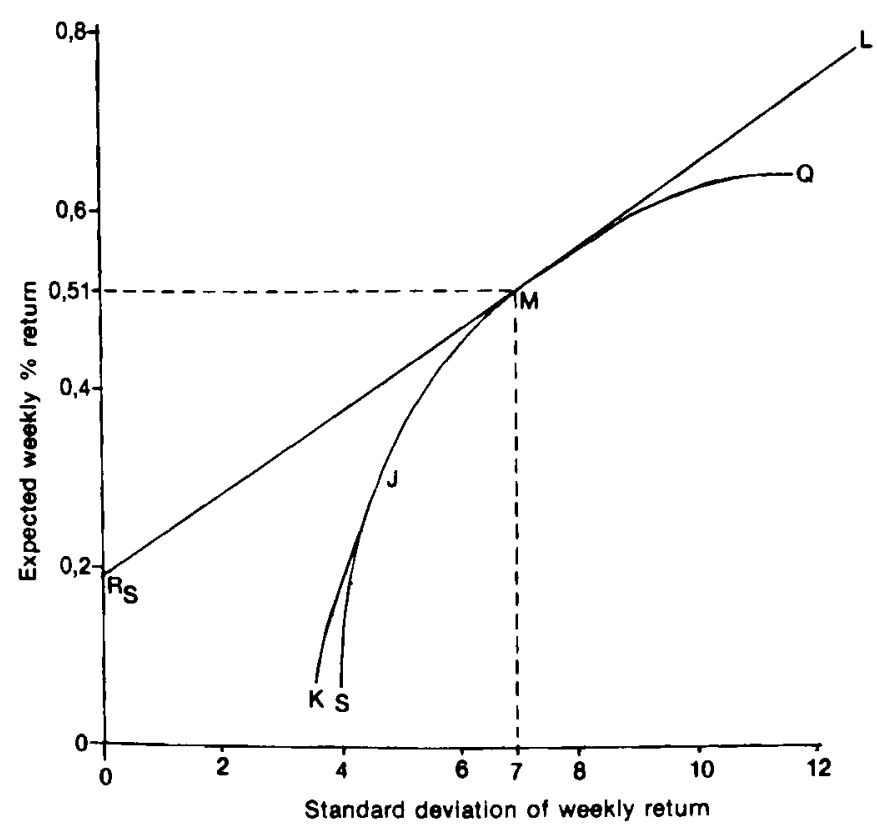

Figure 4 Efficient portfolios of SA gold shares and 1 oz krugerrand. Investment period: 8 January 1981-18 December 1981 (49 weeks)

This confirms the findings of Carter, Affleck-Graves \& Money (1982) in their study of all sectors of the JSE. Because of the difference in the efficient frontiers it is interesting to examine the composition of some of these efficient portfolios in each year.

Portfolios at different risk levels on the efficient frontier for each of the periods under consideration are listed in Tables $2-5$. These portfolios were chosen from the gold share and

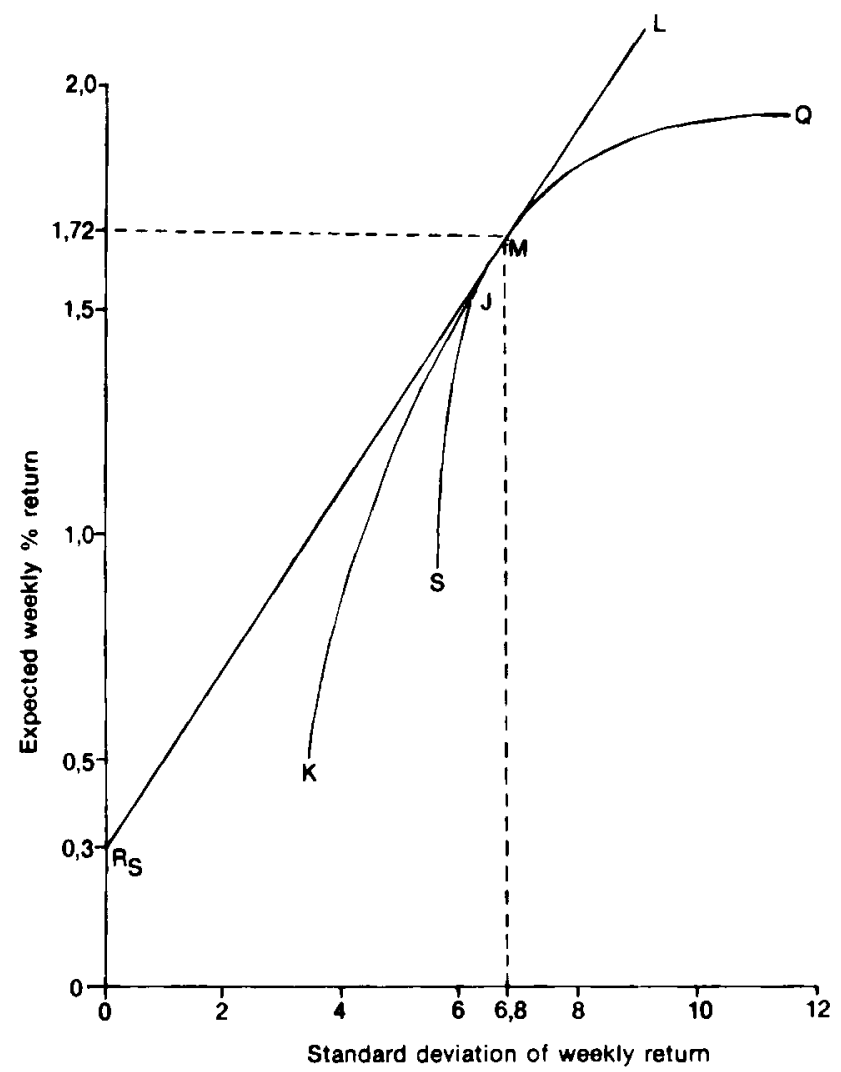

Figure 5 Efficient portfolios of SA gold shares and 1 oz krugerrand. Investment period: 8 January 1982 - 20 December 1982 (51 weeks)

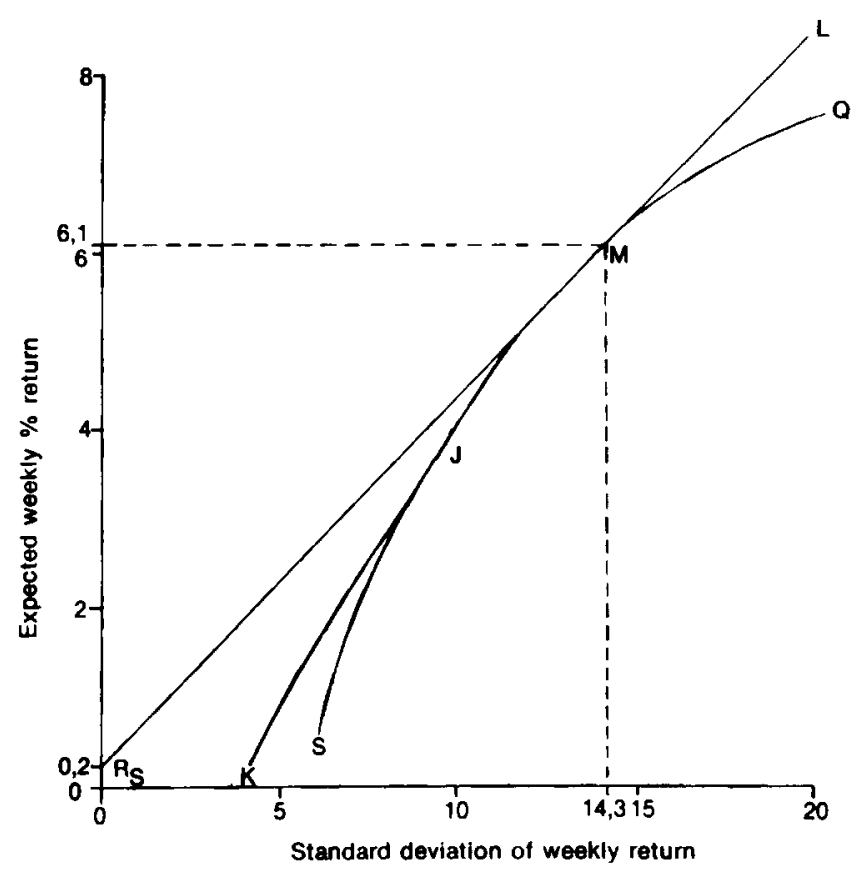

Figure 6 Efficient portfolios of SA gold shares and 1 oz krugerrand. Investment period: 4 January 1983-12 April 1983 (14 weeks)

krugerrand curve, KJMQ, and the portfolio indicated with a double asterisk $\left(^{(*)}\right)$ represents portfolio $M$ in Figures 3-6.

Several points emerge from a study of these tables, the most important of which are summarized below.

(i) At very high risk, high return shares dominate and hence limited diversification occurs.

(ii) As one reduces risk by moving down the efficient frontier, diversification increases. However, this diversification is not as widespread as one might have anticipated with 
Table 2 Efficient portfolios for period 23 May 1980-24 December 1980

\begin{tabular}{|c|c|c|c|c|c|c|c|c|c|c|c|c|c|}
\hline \multirow[b]{2}{*}{ Securities } & \multicolumn{13}{|c|}{ Efficient portfolios } \\
\hline & 1 & 2 & 3 & $4^{* *}$ & 5 & 6 & $\begin{array}{c}\text { KR } \\
\text { EXCL }\end{array}$ & 7 & $\begin{array}{c}\mathrm{KR} \\
\mathrm{EXCL}\end{array}$ & 8 & $\begin{array}{c}\mathrm{KR} \\
\mathrm{EXCL}\end{array}$ & 9 & $\begin{array}{c}\mathrm{KR} \\
\mathrm{EXCL}\end{array}$ \\
\hline E R P M & & . & & & & & & & 1,6 & & 1,8 & & \\
\hline Marvle & & & 2,5 & 4,7 & 6,4 & 5,8 & 3,1 & 5,0 & & & & & \\
\hline Rndfın & & & & & & & 4,3 & 4,0 & 6,5 & 6,7 & 6.6 & 7,0 & \\
\hline Simers & & 14,0 & 9,2 & 7,4 & 3,6 & 2,4 & 1,3 & & & & & & \\
\hline Vlaks & & & & & & & & & 3,5 & & 3,6 & & \\
\hline Braken & & & & & & & & & & & 0,2 & & \\
\hline So Vaal & 100,00 & 32,8 & 19,1 & 12,7 & & & & & & & & & \\
\hline Stlftn & & 40,5 & 56,7 & 60,4 & 66,2 & 58,2 & 62,7 & 46,3 & 51,8 & 23,8 & 51,3 & 22,8 & \\
\hline Zndpan & & & & & & & 6,3 & & 16,6 & & 16,8 & & \\
\hline Welkom & & & 7,0 & 6,7 & 3,4 & & & & & & & & \\
\hline w Holds & & & & & & & 5,2 & & 7,0 & & 7,0 & & \\
\hline Blyvor & & & & 4,6 & 14,7 & 11,0 & 18,0 & 3,1 & 13,2 & & 13,0 & & \\
\hline Doorns & & 12,7 & 3,5 & & & & & & & & & & \\
\hline Dries & & & 2,0 & 3,4 & 5,6 & 6,0 & & 3,7 & 1,7 & & & 1,6 & \\
\hline $\mathrm{K}$ Rand & & & & & & 16,5 & & 38,3 & & 68,0 & & 69,1 & \\
\hline $\begin{array}{l}\text { Expected return } \\
(\% \text { per week) }\end{array}$ & 2,96 & 2,55 & 2,34 & 2,18 & 2,06 & 1,82 & 1,99 & 1,50 & 1,92 & 1,07 & 1,89 & 1,06 & \\
\hline Standard deviation & 7,04 & 4,72 & 4,14 & 3,64 & 3,54 & 3,17 & 3,45 & 2,78 & 3,42 & 2,53 & 3,41 & 2,53 & \\
\hline
\end{tabular}

**Market portfolio (risk-free SA treasury bill introduced)

Table 3 Efficient portfolios for the period 9 January 1981- 18 December 1981

\begin{tabular}{|c|c|c|c|c|c|c|c|c|c|c|c|c|c|}
\hline \multirow[b]{2}{*}{ Securities } & \multicolumn{13}{|c|}{ Efficient portfolios } \\
\hline & 1 & $2^{* *}$ & 3 & 4 & 5 & 6 & $\begin{array}{c}\text { KR } \\
\text { EXCL }\end{array}$ & 7 & $\begin{array}{c}\text { KR } \\
\text { EXCL }\end{array}$ & 8 & $\begin{array}{c}\text { KR } \\
\text { EXCL }\end{array}$ & 9 & $\begin{array}{c}\text { KR } \\
\text { EXCL }\end{array}$ \\
\hline E T Cons & & 60,9 & 67,3 & 23,4 & 0,1 & & & & & & & & \\
\hline Simers & & & & & & & & & & & 2,9 & & \\
\hline Winkel & & & & 47,3 & 30,0 & 29,4 & 23,0 & & 18,0 & & 12,1 & & \\
\hline Val Rfs & & & & & 39,7 & 39,4 & 48,3 & & 53,2 & & 55,3 & & \\
\hline Unisel & & & 2,2 & & & & & & & & & & \\
\hline Dries & & & & & & & & & 2,0 & & 4,0 & & \\
\hline Kloof & & & & 9,6 & 20,7 & 20,5 & 21,6 & & 21,4 & & 21,9 & & \\
\hline E Dagga & 100,00 & 39,1 & 30,5 & 19,6 & 9,6 & 9,4 & 7,0 & & 5,4 & & 4,0 & & \\
\hline K Rand & & & & & & 1,3 & & & & & & & \\
\hline $\begin{array}{l}\text { Expected return } \\
\text { ( } \% \text { per week) }\end{array}$ & & & & & & & & & & & & & \\
\hline $\begin{array}{l}\text { (\% per week) } \\
\text { Standard deviation }\end{array}$ & 0,63 & 0,51 & 0,49 & 0,34 & 0,16 & 0,15 & 0,14 & & 0,12 & & 0,07 & & \\
\hline Standard deviation & 11,7 & 7,0 & 6,44 & 4,98 & 4,17 & 4,14 & 4,11 & & 4,08 & & 4,04 & & \\
\hline
\end{tabular}

**Market portfolio (risk-free SA treasury bill introduced)

a maximum of seven out of the 45 securities considered being held in any one portfolio. This is, of course, in accordance with modern portfolio theory (Wagner \& Lau, 1971).

(iii) No one group of securities dominates. That is, neither the marginal mines nor the long-life mines dominate. Neither does any one JSE sector (geographic location) dominate. In fact, the selection in the various portfolios appears to be somewhat random.

(iv) Krugerrands do not appear in any of the high risk portfolios, as might be expected. However, they do feature fairly strongly in the lower risk portfolios with more than $60 \%$ of the available funds being allocated to krugerrands in the lowest risk portfolio for three of the four periods examined.

(v) Once investment in treasury bills (or some other relat-

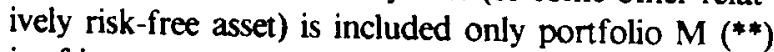
is of importance, that is, the point of tangency between the CML and the efficient frontier. Examination of
Tables 2- 5 shows that for all four periods, portfolio $M$ does not include any krugerrands whatsoever. This can also be seen from Figures $3-6$ where it is clear that the junction of the efficient frontiers (one with and one without the krugerrand) at point $\mathbf{J}$ occurs below point $\mathbf{M}$ in all four periods. The conclusion is clear. In each of the four periods an investor could have earned more return by limiting his investment to a combination of treasury bills and gold shares rather than a combination of gold shares, treasury bills, and the krugerrand. What is more, he could have earned the additional return without increasing his risk.

Therefore, any investor who requires less risk than that offered by portfolio $M$ would be best advised to purchase a combination of treasury bills and portfolio $M$. An investor who wishes to earn a higher return than that offered by portfolio $\mathrm{M}$ would, if unable to borrow, choose one of the portfolios between $M$ and $Q$. In either case, it is clear that krugerrands will not be included in the optimal choice. 
Table 4 Efficient portfolios for period 8 January 1982-20 December 1982

\begin{tabular}{|c|c|c|c|c|c|c|c|c|c|c|c|c|c|}
\hline \multirow[b]{2}{*}{ Securities } & \multicolumn{13}{|c|}{ Efficient portfolios } \\
\hline & 1 & 2 & 3 & $4^{* *}$ & 5 & 6 & $\begin{array}{c}\mathrm{KR} \\
\mathrm{EXCL}\end{array}$ & 7 & $\begin{array}{c}\text { KR } \\
\text { EXCL }\end{array}$ & 8 & $\begin{array}{c}\mathrm{KR} \\
\mathrm{EXCL}\end{array}$ & 9 & $\begin{array}{c}\text { KR } \\
\text { EXCL }\end{array}$ \\
\hline Dbn Dp & & & 9,7 & 7,0 & & & & & & & & & \\
\hline Ergo & & & & & & & & & & & 2,6 & & \\
\hline Randfnt & & 80,9 & 37,5 & 25,1 & & 14,8 & & 10,8 & & & 13,1 & & \\
\hline Simers & & & & 8,8 & 19,7 & 5,9 & 16,3 & 4,7 & 14,2 & & & & \\
\hline Winkel & & & & & 16,1 & & 32,3 & & 36,8 & & 38,9 & & \\
\hline So Vaal & & & 30,3 & 43,5 & 38,7 & 24,3 & 13,8 & 15,8 & 3,4 & & & & \\
\hline Val Rfs & & & & & 11,4 & & 16,8 & & 12,4 & & 6,5 & & \\
\hline P Brand & & & & & & & & & 0,3 & & & & \\
\hline Unisel & & & & & & & 0,4 & & 1,9 & & 2,0 & & \\
\hline W Holds & & & & & & & & & 5,7 & & 9,6 & & \\
\hline Blyvor & & & & & 1,4 & & & & & & & & \\
\hline Deelkrl & & & & & 12,6 & $\cdot$ & 18,1 & & 18,7 & & 18,5 & & \\
\hline Elands & & & & 2,8 & & 3,1 & & 2,6 & & 3,2 & & & \\
\hline Libnon & & & 22,5 & 13,0 & & 7,9 & & 3,8 & & & & & \\
\hline Ventrs & 100,00 & 10,4 & & & & & & & & & & & \\
\hline Rd Leas & & & & & & & 2,3 & & 6,4 & 96,8 & 8,8 & & \\
\hline K Rand & & & & & & 44,0 & & 62,3 & & & & & \\
\hline $\begin{array}{l}\text { Expected return } \\
(\% \text { per week })\end{array}$ & 1,94 & 1,89 & 1,77 & 1,72 & 1,31 & 1,15 & 1,14 & 0,93 & 1,00 & 0,51 & 0,93 & & \\
\hline Standard deviation & 11,54 & 8,08 & 7,06 & 6,8 & 5,92 & 4,94 & 5,74 & 4,30 & 5,68 & 3,4 & 5,67 & & \\
\hline
\end{tabular}

*"Market portfolio (risk free SA treasury bill introduced)

Table 5 Efficient portfolios for period 4 January 1983-12 April 1983

\begin{tabular}{|c|c|c|c|c|c|c|c|c|c|c|c|c|c|}
\hline \multirow[b]{2}{*}{ Securities } & \multicolumn{13}{|c|}{ Efficient portfolios } \\
\hline & 1 & 2 & 3 & $4^{* *}$ & 5 & 6 & $\begin{array}{c}\text { KR } \\
\text { EXCL }\end{array}$ & 7 & $\begin{array}{c}\mathrm{KR} \\
\mathrm{EXCL}\end{array}$ & 8 & $\begin{array}{c}\text { KR } \\
\text { EXCL }\end{array}$ & 9 & $\begin{array}{c}\text { KR } \\
\text { EXCL }\end{array}$ \\
\hline Simers & & & 8,6 & 13,3 & 20,0 & 8,1 & 1,6 & 4,9 & & 2,0 & & 1,4 & \\
\hline Village & & & & 4,1 & 10,0 & & 10,3 & & 8,7 & & & & \\
\hline W R Cons & & 62,0 & 44,4 & 39,2 & 32,0 & 10,2 & & 6,2 & & 2,7 & & & \\
\hline So Vaal & & & & & & & 25,9 & & 32,4 & & & & \\
\hline Zndpan & & & & & & & 59,7 & & 58,9 & 7,8 & & 9,8 & \\
\hline E Dagga & 100,00 & 38,1 & 29,9 & 27,3 & 23,5 & 7,6 & 2,6 & 4,3 & & 2,5 & & 1,2 & \\
\hline Rd Leas & & & 17,1 & 16,1 & 14,8 & 6,1 & & 3,3 & & & & & \\
\hline K Rand & & & & & & 68,0 & & 81,3 & & 85,0 & & 88 & \\
\hline $\begin{array}{l}\text { Expected return } \\
\text { (\% per week) }\end{array}$ & 7,52 & 7,27 & 6,48 & 6,1 & 5,56 & 1.76 & 1,15 & 0,96 & 0,89 & 0,4 & & 0,11 & \\
\hline Standard deviation & 20,62 & 17,01 & 15,33 & 14,3 & 13,56 & 6,73 & 6,66 & 5,39 & 6,36 & 4,52 & & 4,09 & \\
\hline
\end{tabular}

**Market portfolio (risk free SA treasury bill introduced)

\section{Ex-post vs ex-ante arguments}

One possible drawback of the above results is that the study was performed on an ex-post basis whereas in practice investors must act ex-ante; that is, they must use estimates of the expected return and risk for each security for the coming period. Nevertheless, we believe that ex-post studies are of value in that they demonstrate the investment opportunities that were actually available in the period. Any consistent results which appear would indicate areas in which investors appear to be making systematic error. This should obviously be of interest to all investors although they must ask themselves whether or not the situation is likely to continue.

In the case of the krugerrand vs gold shares debate, however, an attempt can be made to examine the ex-ante question in addition to the ex-post analysis above. From an ex-ante position, the efficient market hypothesis (EMH) (Fama, 1970) implies that the investor can do no better than to buy 'the market'. As far as the market in gold shares is concerned, the JSE Actuaries All Gold Index can be used as a surrogate. Therefore, to examine the ex-ante situation, the performance of a gold investor who bought the market (i.e. the All Gold Index) can be contrasted with the performance of an investor who divided his funds between the krugerrand and the gold index. This was done using the Markowitz approach described earlier and the results are shown in Figures $7-9$.

It is important to note that the curves KMQ in Figures 7-9 represent the efficient frontier for an investor faced with only two alternatives - the gold index and/or the krugerrand. Also, because both the krugerrand and the gold share index resulted in losses in 1981 an ex-ante analysis is meaningless and has therefore been excluded. Figure 10 which indicates the situation for the entire period has been included instead. Finally, note that the capital market line has also been included which indicates the opportunities available to an investor who was faced with three alternatives; the krugerrand, the gold 


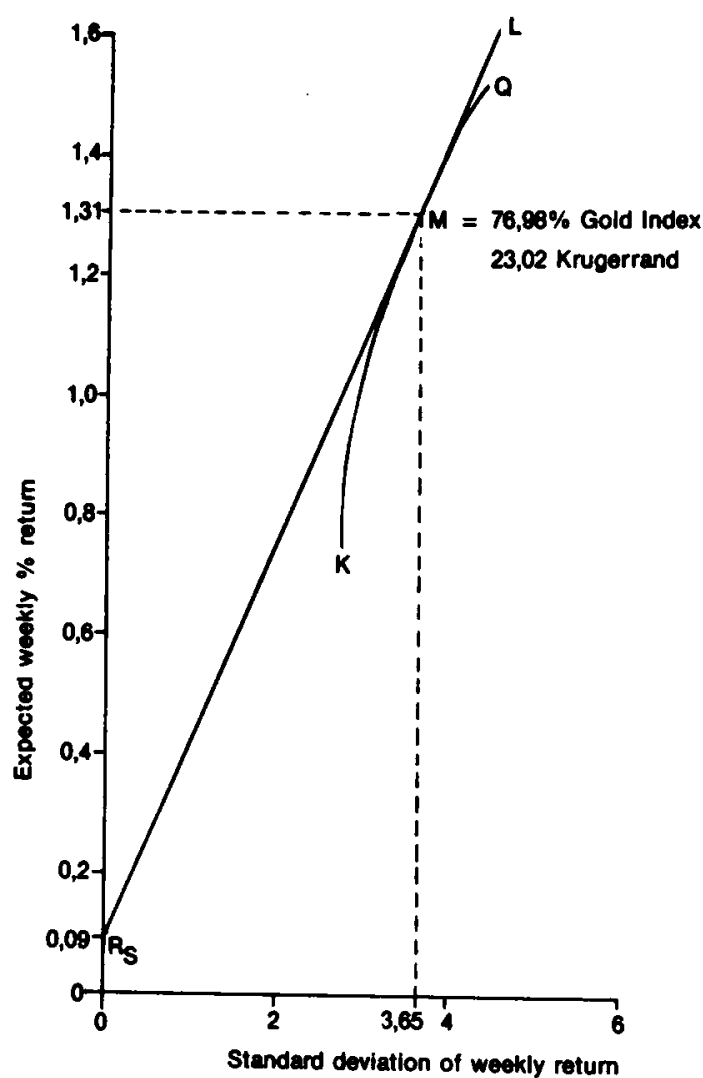

Figure 7 Efficient portfolio curve of gold index and $10 z$ krugerrand. Investment period: 23 May 1980-24 December 1980 (32 weeks)

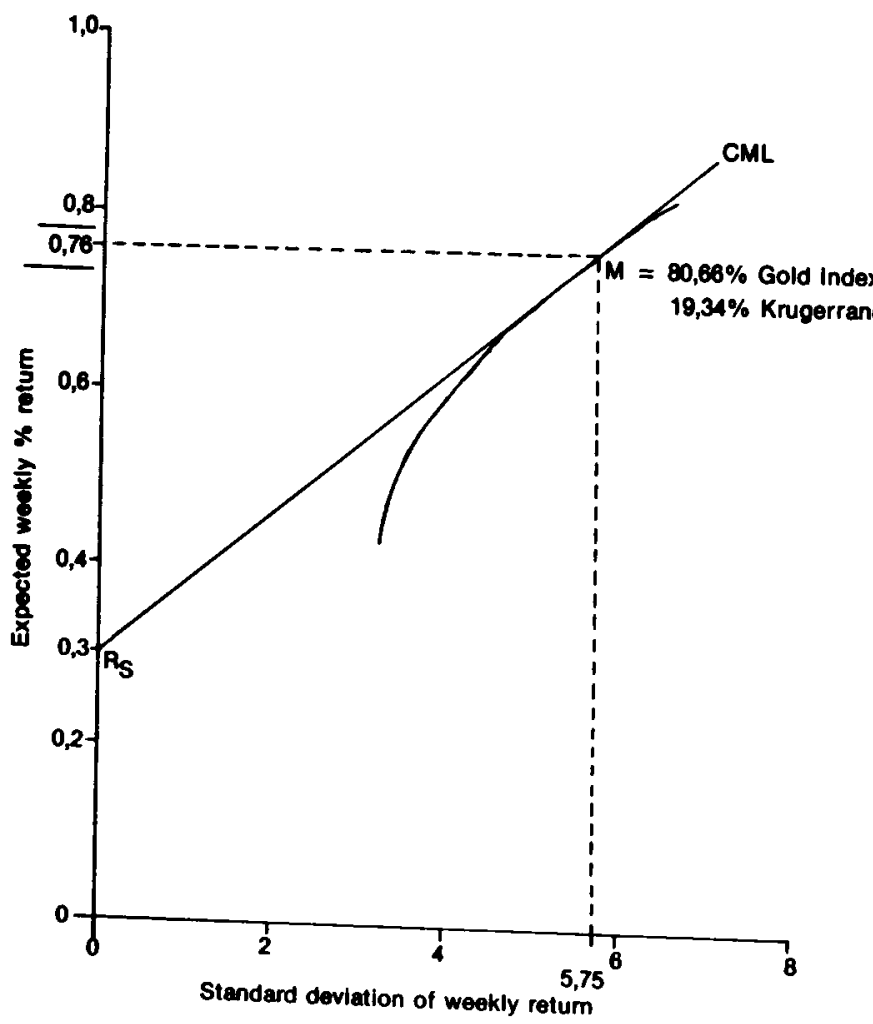

Figure 8 Efficient portfolio curve of gold index and 1 oz krugerrand Investment period: 8 January 1982-20 December 1982 (51 weeks)

share index and treasury bills. The results indicated by Figures 7-10 are summarized in Table 6.

The results clearly show that at best limited investments should be made in the krugerrand. In fact, no more than $20 \%$ of funds available for investment in gold-related investments should be allocated to the krugerrand, probably even less.

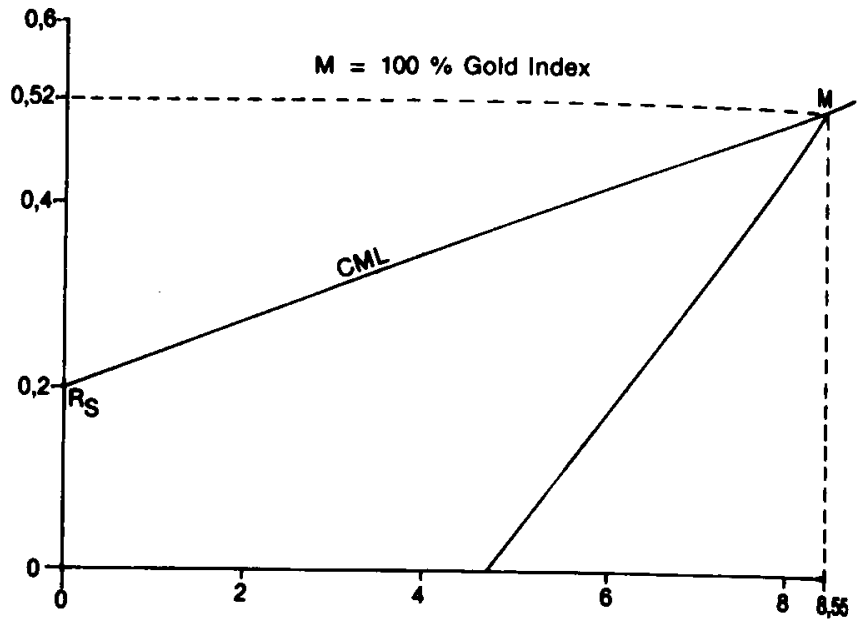

Figure 9 Efficient portfolio curve of gold index and 1 oz krugerrand. Investment period: 4 January 1983-12 April 1983 (14 weeks)

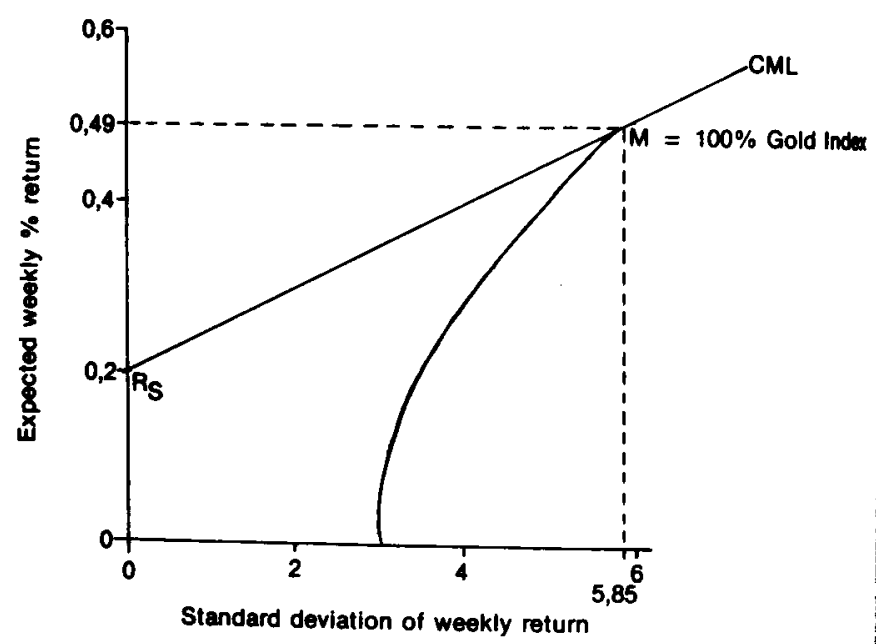

Figure 10 Efficient portfolio curve of gold index and 1 oz krugerrand. Investment period: 23 May 1980-12 April 1983(147 weeks)

Table 6 Composition of Portfolio $M$ for different periods.

\begin{tabular}{lcc}
\hline Period & $\begin{array}{c}\text { \% in gold } \\
\text { share index }\end{array}$ & $\begin{array}{c}\% \text { in } \\
\text { krugerrand }\end{array}$ \\
\hline $23.05 .80-24.12 .80$ & 77 & 23 \\
$08.01 .82-20.12 .82$ & 81 & 19 \\
$04.01 .83-12.04 .83$ & 100 & - \\
$23.05 .80-12.04 .83$ & 100 & - \\
\hline
\end{tabular}

\section{Conclusion}

The overall conclusion one can draw from the above results is that relative to gold shares, the krugerrand has proved historically to be a poor investment. In general, over the period considered the krugerrand provided less return than did the gold shares on average. Moreover, this reduction in return was not compensated for by an adequate reduction in risk and in fact in the bear phase of 1981 the krugerrand price fell more than the JSE Actuaries All Gold Index. The result is that an investor who considers himself a superior analyst as regards gold shares should clearly not invest any of his funds in the krugerrand. For the naive investor the best strategy would probably be to divide his funds between a 'gold index' portfolio and treasure bills. If he did decide to invest in krugerrands the amount invested therein should be small - certainly no more than $20 \%$ of hic funds 


\section{References}

Carter, K.J., Affleck-Graves, J.F. \& Money, A.H. 1982. Unit Trusts and Portfolio Selection on the Johannesburg Stock Exchange. S. Afr. J. Bus. Mgmt., vol 13, 169-175.

Fama, E.F. 1970. Efficient Capital Markets: A Review of Theory and Empirical Work. J. Fin., vol. 25, 383-417.

Markowitz, H.M. 1952. Portfolio Selection. J. Fin., vol. 7 , $77-91$.

Sharpe, W.F. 1964. Capital Asset Prices: A Theory of Market Equilibrium under Condition of Risk. J. Fin., vol.19, $425-442$

Wagner, W.H. \& Lau, S.C. 1971. The Effect of Diversification on Risk. Fin. Anal. J., vol. 25, 7-13.

\section{Appendix A}

1. Durban Roodepoort Deep Ltd

2. East Rand Proprietary Mines Ltd

3. East Rand Gold and Uranium CO Ltd

4. Eastern Transvaal Consolidated Mines Ltd

5. The Grootvli Proprietary Mines Ltd

6. Marievale Consolidated Mines Ltd

7. Consolidated Modderfontein Mines Ltd

8. The Randfontein Estates Gold Mining Co, Witwatersrand Ltd

9. South African Land and Exploration Co Ltd

10. Simmer and Jack Mines Ltd

11. Village Main Reef Gold Mining Co (1934) Ltd

12. Vlakfontein Gold Mining Co Ltd

13. West Rand Consolidated Mines Ltd
14. Witwatersrand Nigel Ltd

15. Bracken - Bracken Mines Ltd

16. Kinross - Kinross Mines Ltd

17. Leslie - Leslie Gold Mines Ltd

18. Winkels - Windelhaak Mines Ltd

19. Af Lease - The Afrikander Lease Ltd

20. Buffels - Buffelsfontein Gold Mining Co Ltd

21. Harties - Hartebeesfontein Gold Mining Co Ltd

22. Sovaal - Southvall Holdings Ltd

23. Stilfnt - Stilfontein Gold Mining Co Ltd

24.. Vaal Reefs Exploration and Mining Co Ltd

25. Zandpan Gold Mining Co Ltd

26. Free State Geduld Mines Ltd

27. Harmony Gold Mining Co Ltd

28. Loraine Gold Mines Ltd

29. President Brand Gold Mining Co Ltd

30. President Steyn Gold Mining Co Ltd

31. St Helena Gold Mining Company Ltd

32. Unisel Gold Mines Lid

33. Welkom Gold Mining Co Ltd

34. Western Holdings Ltd

35. Blyvooruitzicht Gold Mining Co Ltd

36. Deelkraal Gold Mining Co Ltd

37. Doornfontein Gold Mining Co Ltd

38. Driefontein Consolidated Ltd

39. Elandsrand Gold Mining Co Ltd

40. Elsburg Gold Mining Co Ltd

41. Kloof Gold Mining Co Ltd

42. Libanon Gold Mining Co Ltd

43. Venterspost Gold Mining Co Ltd

44. Western Areas Gold Mining Co Ltd

45. Western Deep Levels Ltd 